\title{
10
}

\section{Ekoturizem in zavarovana območja}

\section{Simon Kerma}

UP Fakulteta za turistične študije - Turistica

simon.kerma@fts.upr.si

Matej Vranješ

UP Fakulteta za turistične študije - Turistica

matej.vranjes@fts.upr.si

\section{Uvod}

Po drugi svetovni vojni smo priča silovitemu družbeno-ekonomskemu razvoju na vseh področjih človekovega delovanja. Predvsem imamo v mislih pospešeno industrializacijo, motorizacijo in tehnizacijo, ki med drugim dajejo zagon ter pospešek tudi rasti in koncentraciji turizma (zlasti v 6o. in 7o. letih prejšnjega stoletja). Intenzivni »razvoj« privede do pojava t.i. množičnega turizma, torej do krepko povečanega (nesorazmerno velikega) števila turistov v določenem času (turistični sezoni) in prostoru (turističnem kraju ali destinaciji). Posledično so tudi (negativni) vplivi turizma vse pogostejši in intenzivnejši, kar v 8o. letih 20. stoletja - vzporedno z uveljavljanjem koncepta trajnostnega razvoja - privede do potrebe po drugačnem in predvsem do okolja in naravnih virov prijaznejšem turizmu, ki naj bi predstavljal konceptualno nasprotje in protiutež množičnemu. Govorimo torej o alternativnem turizmu, ki je okolju neškodljiv ali manj škodljiv, pridružijo pa se mu številne druge opredelitve 
in pojavne oblike, kot so: ekološko usmerjeni, ekološko in socialno sprejemljivi, tihi, mirni, nemotorizirani ali netehnizirani, k naravi usmerjeni, okolju prijazni, ekstenzivni, prilagojeni, nišni, enostavni, mehki, kakovostni, integrirani, izobraževalni, odgovorni turizem idr. (Mihalič, 2006, str. 87-90; Weaver, 2006, str. 38-57).

\section{Pojav ekoturizma in nekatere dileme pri njegovem definiranju}

Kritični odgovor na množični turizem in z njim povezane okoljske apetite turistične »industrije« izhaja iz naraščajoče globalne ekološke zavesti in se odraža predvsem v skrbi po ohranjanju kakovostnega okolja. Stališče, da se turizem mora integrirati v zaščito in ohranjanje narave, zagovarja že Budowski (1976). Takrat se tudi pojavi termin »ekorazvoj«, ki naj služi kot orodje za zmanjšanje škodljivega vpliva na okolje (Fennell, 2008). Do pojava ekoturizma je tako le še korak, a nekega konsenza med teoretiki in raziskovalci o tem, kdaj točno je pojem nastal in kdo ga je prvi uporabil, še ni. Strinjajo se, da je ekoturizem precej kompleksen fenomen, ki se v različnih pojavnih oblikah razvija zdaj že dobrih tridesetih let.

Weaver (2006, str. 192) začetke ekoturizma sredi osemdesetih let prejšnjega stoletja povezuje z mehiškim krajinskim arhitektom Héctorjem Ceballos-Lascuráinom, ki je tudi prvi podal definicijo ekoturizma. Po njegovem gre za potovanje v relativno nedotaknjeno ali neokrnjeno naravno okolje $\mathrm{z}$ namenom preučevanja, občudovanja in uživanja v lepotah pokrajine, tako v rastlinstvu in živalstvu kakor tudi v obstoječih (preteklih in sedanjih) kulturnih vidikih na obiskanem območju (Ceballos-Lascuráin, 1988, v Weaver, str. 2006). Široka uporaba pojma sovpada z razvojem paradigme trajnostnega razvoja, pri čemer naj bi ekoturizem predstavljal najtrajnostnejšo zvrst ali obliko turizma oz. celo zavest trajnostnega turizma (Weaver, 2006, str. 191).

Tudi Fennell (1999, v Weaver, str. 2006) ekoturizem razlaga kot trajnostno obliko turizma, ki temelji na naravi in se osredotoča predvsem na njeno doživljanje in spoznavanje, je etično usmerjen in naklonjen lokalnemu prebivalstvu. Ekoturizem tako ne predstavlja več zgolj nekega fenomena, temveč vzpostavlja široko akademsko in prakseološko polje z različnimi konteksti in perspektivami (drugačen razvoj na različnih koncih sveta), kar navsezadnje povzroča tudi določene težave pri oblikovanju konsenza o splošno sprejemljivi de- 
finiciji in posledično zavira vzpostavitev poenotene (celovite) teorije o ekoturizmu (Hunt in Stronza, 2009).

Poglobljen teoretski razmislek in akumulacija praktičnih primerov privedeta do dokončne uveljavitve ekoturizma takoj po prelomu tisočletja, ko se dotedanja spoznanja artikulirajo v obsežni monografiji The Encyclopedia of Ecotourism (Weaver, 2001), od leta 2002 pa redno izhaja ugledna znanstvena revija Journal of Ecotourism (https://www.tandfonline.com/loi/reco2o). Ekoturizem je takrat dejansko v središču pozornosti turistične srenje, saj se leto 2002 obeležuje kot mednarodno leto ekoturizma. Kulminacija pestrega dogajanja je mednarodna konferenca pod okriljem Programa Združenih narodov za okolje (United Nations Environmental Programme - UNEP) in Svetovne turistične organizacije (World Tourism Organization), ki jo gosti kanadski Quebec City. Vrhunec konference predstavlja oblikovanje quebeške deklaracije o ekoturizmu, ki vsebuje temeljne ugotovitve in tudi vrsto priporočil vladam, zasebnemu sektorju in nevladnim organizacijam za načrtovanje, upravljanje, razvoj, trženje in nadzorovanje ekoturističnih aktivnosti s ciljem trajnega sonaravnega gospodarskega razvoja. Glavni namen deklaracije je prispevati k ohranjanju naravne in kulturne dediščine ter zagotoviti njuno aktivno in verodostojno interpretacijo, zelo se izpostavlja tudi pomen sodelovanja lokalnih skupnosti pri turističnem načrtovanju (Québec Declaration on Ecotourism, 2002).

V korak s časom je tedaj stopila tudi slovenska turistična stroka, ki je pod okriljem Turistične zveze Slovenije pripravila posvet in izdala publikacijo Razvoj ekoturizma $v$ Sloveniji (Turistična zveza Slovenije, 2003). Pregled objav na temo ekoturizma v slovenskem jeziku preko sistema сов ISs (aprila 2020) pokaže kontinuirano in živahno strokovno aktivnost vse do danes, kar zlasti velja za zaključna diplomska in magistrska dela (skoraj $55 \%$ vsega gradiva), preseneča pa deficit znanstvenih objav (le dobrih $5 \%$ vseh objav o ekoturiz$\mathrm{mu}$ ). Prav tako velja opozoriti na terminološko zmedo, ki se pri nas še vedno pojavlja $\mathrm{v}$ povezavi $\mathrm{z}$ razumevanjem pojma ekoturizem, ki se poljubno zamenjuje s trajnostnim, z zelenim, odgovornim, s podeželskim, z geo-, bio-, ekološko odgovornim in naravnim turizmom, če omenimo zgolj tiste najpogostejše "sopomenke« (Bodi eko, b.l.; Primožič, 2014, str. 6-8).

Če se vrnemo k definicijam, ne moremo mimo nekaterih relevantnih mednarodnih organizacij, ki so tesno povezane z ekoturiz- 
mom. Na prvem mestu je potrebno omeniti Mednarodno združenje za ekoturizem (The International Ecotourism Society), ki je bilo ustanovljena že leta 1990 in velja za najstarejšo (nevladno in neprofitno) ekoturistično organizacijo na svetu. Ekoturizem Mednarodno združenje za ekoturizem definira kot »odgovorno potovanje v naravna območja, ki ohranja okolje, vzdržuje blaginjo lokalnih prebivalcev ter vključuje interpretacijo in izobraževanje [tako gostiteljev kot obiskovalcev] « (The International Ecotourism Society, 2015). Mednarodna zveza za ohranjanje narave (International Union for Conservation of Nature) se v dobršni meri nasloni na definicijo CeballosLascuráina, pri čemer - poleg minimalnega negativnega vpliva obiskovalcev na okolje - kot še posebej pomembno komponento ekoturizma izpostavi aktivno vlogo lokalnega prebivalstva in s tem povezane družbeno-ekonomske koristi (Primožič, str. 2014). Pri krovni Svetovni turistični organizaciji pa se pri definiranju sklicujejo na naslednje značilnosti ekoturizma (World Tourism Organization, 2020):

1. Vključuje vse na naravi temelječe oblike turizma, pri katerih je glavna motivacija turistov opazovanje ter spoštovanje narave in tradicionalnih kultur, prisotnih $\mathrm{v}$ teh naravnih okoljih.

2. Vsebuje izobraževalne in interpretacijske vsebine.

3. Praviloma (ne pa izključno) so ekoturistična potovanja v domeni specializiranih organizatorjev potovanj za majhne skupine. Partnerji ponudnikov storitev na destinacijah so navadno manjša samostojna lokalna podjetja.

4. Zmanjšuje negativne vplive na naravno in družbeno-kulturno okolje.

5. Vzdržuje naravna območja, ki so hkrati ekoturistične atrakcije, tako da:

- ustvarja gospodarske koristi za gostiteljske skupnosti, organizacije in upravljavce, ki so odgovorni za ohranjanje naravnega okolja;

- zagotavlja alternativne možnosti zaposlitve in dohodka za lokalno prebivalstvo;

- povečuje ozaveščenost o ohranjanju naravnih in kulturnih dobrin, tako med domačini kot turisti.

Poznamo torej različne opredelitve ekoturizma, ki pa so večinoma utemeljene v osnovni filozofiji koncepta in vključujejo vsaj tri bistvene komponente, in sicer da je ekoturizem (1) usmerjen v naravo, (2) 
izpostavlja izobraževalni vidik in da si (3) prizadeva za ohranjanje in varovanje okolja (Nowaczek in Smale, 2010), pri čemer je fokus (eko)turistične izkušnje praviloma naravno, včasih pa tudi kulturno okolje (Weaver, 2006). Učenje o okolju in njegovo spoštovanje sta pričakovana rezultata interakcije med turistom in obiskano destinacijo, trajnostni cilji ekoturizma pa v tem smislu morajo upoštevati ekonomski, sociokulturni in okoljski vidik (Perkins in Grace, 2009).

Tako kot še vedno ni docela poenotene in splošno sprejete definicije ekoturizma, se v literaturi posledično pojavljajo tudi različne opredelitve in določitve profila ekoturista. Skušnjave in nenehne potrebe turistične industrije po segmentaciji trga za marketinške namene večkrat privedejo do dileme, kako potegniti ločnico med različnimi vrstami in oblikami turizma ter med različnimi profili turistov. Podobno ugotavlja P. Wight (2001) za ekoturizem in ekoturiste. T. Primožič (2014) primerja študije in tipologije različnih avtorjev, ki ekoturiste tipizirajo predvsem po stopnji okoljske ozaveščenosti. Na tej osnovi skuša opredeliti splošni profil ekoturista, ki ga določi po starosti, spolu, izobrazbi in statusu ter stroških, elementih (vsebini), načinu, trajanju in motivih za izbiro ekoturističnega potovanja (Primožič, 2014, str. 30).

A bolj kot poskus določitve nekega povprečnega (in težko določljivega) profila ekoturista se vendarle zdi primernejša Weaverjeva tipologija, ki polje ekoturizma (in s tem tudi ekoturistov) umesti v dihotomijo dveh idealnih tipov (skrajnosti), to je »tršega « in »mehkejšega" (slika 10.1). Trša dimenzija je bolj zavezujoča in naslavlja ekoturiste, katerih glavni motiv je spoznavanje, izobraževanje in prispevanje k ohranjanju naravnega okolja, medtem ko so pri mehkejših ekoturistih v ospredju opazovanje $\mathrm{z}$ interpretacijo, fizična pasivnost in udobje, pri čemer je ohranjanje narave bolj ali manj odvisno od organizacije same ponudbe (Weaver, 2006, str. 194-201).

\section{Prostorska prilagodljivost ekoturističnih prizorišč}

Velika večina definicij ekoturizma, kot povzema Weaver (2006, str. 200), kot primerna prizorišča za to zvrst turizma predpostavlja relativno nedotaknjena oz. dobro ohranjena naravna okolja. Razvoj različnih oblik ekoturizma od 9o-ih let prejšnjega stoletja dalje večinoma res stimulira povpraševanje po turističnih produktih, ki prevladujoče (ne pa izključno) vključujejo raznovrstne vsebine iz narave. Povpraševanje po turizmu v naravi je tako že vrsto let v stalnem po- 
Trši (aktiven, poglobljen)

Močna zavezanost okolju

Okrepljena trajnostnost

Specializirana potovanja

Dolga potovanja

Majhne skupine

Fizična aktivnost

Fizični izziv

Malo ali nič pričakovanih storitev

Poudarek na osebni izkušnji

Lasten aranžma potovanja
Mehkejši (pasiven, plitek)

Zmerna zavezanost okolju

Trajnostna stabilnost

Večnamenska potovanja

Kratka potovanja Večje skupine

Fizična pasivnost Fizično udobje

Pričakovane storitve

Poudarek na interpretaciji

Zanašanje na agente in turistične agencije

Slika 10.1 Prikaz značilnosti dveh skrajnih idealnih tipov ekoturizma tršega in mehkejšega (prirejeno po Weaver, 2006, str. 195)

rastu in posledično je tudi ponudba ekoturizma med najhitreje rastočimi turističnimi proizvodi. Fennell (2008) je tako že pred dobrim desetletjem ocenjeval, da ekoturizem zavzema vsaj 30-odstotni turistični delež v svetovnem merilu. To v veliki meri sovpada $\mathrm{z}$ obsegom mednarodnega turističnega obiska $v$ zavarovanih območjih narave, tako po prihodih kot tudi prihodkih, kar bo nekoliko podrobneje predstavljeno v nadaljevanju. Naravne lepote in atrakcije so med motivi tujih turistov pri odločanju za njihov prihod že vrsto let izpostavljene tudi kot najpomembnejši razlog za obisk Slovenije (Slovenska turistična organizacija, 2019). Paleta turistične ponudbe vključuje vse od predanega opazovanja in preučevanja naravnih rezervatov do rekreacijskega udejstvovanja v naravi, ko ta obiskovalcem predstavlja »zgolj« nekakšno prijetno kuliso (Jurinčič, 2009).

Podeželje, ki je antropogeni prostor (četudi blizu naravi), prav tako nudi veliko možnosti za razvoj ekoturizma, pri čemer še posebej izstopajo ekološke turistične kmetije s ponudbo kakovostne hrane in nastanitvijo v avtentičnem okolju. Podmenik in sodelavci (2012) podrobneje analizirajo turistično ponudbo na ekoloških kmetijah pri nas in preučijo možnosti za njeno nadaljnjo krepitev in širitev. Menijo, da gre v primeru turizma na ekoloških turističnih kmetijah celo za najavtentičnejšo ponudbo ekoturistične izkušnje v Sloveniji, še posebej na tistih ekoloških kmetijah, ki ležijo v zavarovanih območjih narave (Podmenik idr., 2012, str. 130). Da ima turizem na ekoloških kmetijah - kljub nekaterim zaznanim oviram in pomanjkljivostim velik razvojni potencial, ugotavljajo tudi Kerma idr. (2014), ko preučujejo razvoj (eko)turizma kot dopolnilne dejavnosti na primorskih 
ekoloških kmetijah. Naslonijo se na teoretsko razpravo in empirično analizo, ki sta jo na primeru južnokorejskih ekoturističnih kmetij opravila H. Choo in Jamal (2009). Avtorja v svojem prispevku turizem na ekoloških kmetijah (angl. eco-organic farm tourism) postulirata kot novo obliko ekoturizma, katerega principi se lahko koristno aplicirajo kot vodilna trajnostna paradigma za manjše ekološke kmetije, a se hkrati zavedata dejstva, da nekatere ekološke kmetije morda tudi niso primerne za razvoj ekoturističnih aktivnosti (Choo in Jamal, 2009, str. 431).

Čeprav se vsaj na prvi pogled zdi nenavadno oz. kontradiktorno, pa je razvoj ekoturizma možno misliti in udejanjati tudi v urbanih okoljih. Avtorji navajajo različne primere mestnih parkov, hribov, rečnih dolin in otokov, celo živalskih vrtov in golf igrišč, opuščenih zaraščenih oz. zelenih površin (glej npr. Weaver, 2006, str. 200-201). Če malce pomislimo, lahko tudi pri nas identificiramo kar nekaj urbanih ali suburbanih prizorišč, kjer bi bilo možno izvajati ekoturistične programe oz. ti tam že potekajo. Ljubljana, ki se na spletnih straneh Slovenske turistične organizacije (https://www.slovenia.info) predstavi kot "zelena prestolnica zelene države« in se ponaša z nazivom Zelena prestolnica Evrope 2016 ter uvršča med sto najtrajnostnejših destinacij na svetu, ima v resnici veliko vodnih in zelenih, tudi zavarovanih površin (npr. Krajinski park Tivoli, Rožnik in Šišenski hrib). V najbolj urbanem prostoru Slovenije si torej brez težav predstavljamo razvoj ekoturističnih vsebin, ki kombinirajo relativno dobro ohranjeno (vzdrževano) naravo in (sub)kulturne, zlasti alternativne posebnosti glavnega mesta, vključno s primeri trajnostne mobilnosti. Kot drugi primer pa bi lahko navedli Naravni rezervat Škocjanski zatok, torej zavarovano območje v neposredni bližini Kopra in Luke Koper, katerega upravljavec DoPPS na svojih spletnih straneh takole povabi obiskovalce v rezervat: »Pridružite se nam in doživite največje slovensko polslano mokrišče, ujeto v urbano okolje, in se tako prepričajte o uspešnem sobivanju narave in človeka.« (Naravni rezervat Škocjanski zatok, 2020)

Splošna percepcija in razumevanje ekoturizma, da je to ena od zvrsti turizma v naravi (na naravi temelječ turizem oz. angl. naturebased tourism), potemtakem res ni tako enoznačna. Videli smo, da ekoturistično ponudbo lahko razvijamo tudi na podeželju in $\mathrm{v}$ (sub)urbanem okolju. Podobno velja za zavarovana območja (narave), ki niso izključno naravna (že dejstvo, da so zavarovana, pomeni, 
da gre pri tem za družbeni konstrukt), saj vanje bolj ali manj občutno posega tudi človek s svojimi aktivnostmi. Vsekakor gre za območja posebnega pomena, ki se v kontekstu razvoja turizma zdijo kot naročena prizorišča ravno za ekoturizem.

\section{Zavarovana območja narave in (eko)turizem nekoč in danes}

Glede na »splošno uveljavljene« opredelitve ekoturizma (kot npr. Weaver, 2006, str. 192-196; Wearing in Neil, 1999, str. 7-9) lahko torej rečemo, da turizem, ki se izvaja $\mathrm{v}$ zavarovanih območjih narave $(\mathrm{v}$ nadaljevanju zo), v veliki meri, ne pa izključno, spada pod ekoturizem. Še z večjo gotovostjo lahko zatrdimo tudi obratno: velik delež ekoturizma se zaradi značilnosti in pomena zavarovanih območij izvaja ravno v njih. Še natančneje bi morali reči, da bi turizem, ki ga izvajajo upravljavci zavarovanih območij sami, moral biti ekoturizem, kar pa ne velja nujno za turizem, ki ga v zavarovanih območjih (in tega je bistveno več) izvajajo ostali ponudniki.

Čeprav imajo zavarovana območja dokaj jasne zakonodajne in upravne okvirje, ki določajo možne oblike ali zvrsti in obseg turizma, se je potrebno zavedati, da je podlaga tem okvirjem predvsem soočanje družbenih vrednot. Razvoj turizma v nekem zavarovanem območju je izraz njegovih naravnih značilnosti oz. materialnih pogojev, geografske lege, lokacije trgov, ekonomskega razvoja in trendov v globalnem turizmu nasploh, a hkrati odseva spreminjajoč se odnos med družbo/kulturo in naravo. Zgodovinsko gledano je že sam pojav zavarovanih območij povezan s spremembo v družbenem pogledu na naravo, ki je osnova za razvoj turizma: gre za pojav vrednotenja "neokrnjene« narave skozi njeno estetsko in človekovemu uživanju namenjeno funkcijo. Prva prizadevanja za posebno zaščito območij narave se v »razvitem svetu « namreč pojavijo kmalu za novim pogledom na divjino, ki ga v prvi polovici 19. stoletja prineseta popularizacija naravoslovja in zlasti romantika (McCormick, 1995, str. 1-24). Povedano poenostavljeno: če je divja, "neukročena" narava v industrijsko se razvijajočih družbah do romantike imela status nevarnega in nekoristnega sveta, vrednega toliko, kolikor človeku lahko služi kot sredstvo nadaljnjega gospodarskega razvoja, »romantik« divjino ceni ravno zaradi njene pristnosti, neukročenosti, prvinskosti, izjemne pokrajinske lepote, zdravilnih učinkov, zaradi "vračanja človeka k naravi«. Prva zavarovana območja so bila tako območja (relativne) divjine, namenjena v prvi vrsti obiskovanju 
oz. rekreaciji in ne zaščiti narave zaradi vrednosti narave same (Wearing in Neil, 1999, str. 40; McManus, 2000, str. 532-533). Yellowstone, ki velja za prvi narodni park na svetu (ustanovljen l. 1872), je bil npr. izvorno zasnovan kot območje zabave v korist in uživanje ljudem, za pridobivanje velikega zaslužka od turistov in iskalcev užitka ter kot nacionalno območje za počitek in rekreacijo (Wearing in Neil, 1999, str. 40). Podobno je veljalo tudi za prve parke, ustanovljene nekoliko kasneje drugod v industrijsko razvijajočem se svetu (ZDA, Avstralija, Švedska itd.).

Ne glede na izrazito utilitarno funkcijo prvih parkov je bilo ustanavljanje zavarovanih območij do konca druge svetovne vojne počasno, izrazito pa se proces pospeši od 50-ih, 6o-ih let 20. stoletja dalje, ko se ostankom »romantičnih « pogledov pridruži vznik sodobne naravovarstvene misli, ki zahteva zaščito narave in biodiverzitete same, kar je še danes osnovni namen ustanavljanja zavarovanih območij. V 7o-ih letih se tako število parkov podvoji, industrijsko razvitim državam se pridružijo tudi države v razvoju (Rotich, 2012, str. 173; Wearing in Neil, 1999, str. 39). Za razumevanje razvoja ekoturizma je pomembno tudi to, da v "pionirski« dobi ob ustanavljanju parkov sodelovanje z lokalnimi skupnostmi in drugimi deležniki ni bilo pomembno, medtem ko je danes to ena od osrednjih nalog upravljalcev in okoljske politike.

Podoben primer opisane razvojne krivulje je tudi Triglavski narodni park (TNP). Kot eno najstarejših zavarovanih območij v Evropi je bil (kot Alpski varstveni park) ustanovljen že l. 1924, a zajemal je le del »divjine«, idilično Dolino Triglavskih jezer z »očakom» Triglavom. Šele z razmahom naravovarstvene misli se leta 1981 ustanovi TNP V obsegu, kot ga poznamo danes. Ob ustanavljanju prvega in drugega TNP interesi lokalnih skupnosti niso bili ravno upoštevani, medtem ko sta se procesa sprejemanja novega Zakona o Triglavskem narodnem parku (ZTNP-1) (2010) in prvega načrta upravljanja (1. 2016) razvlekla na več let ravno zaradi soočanja interesov in mnenj različnih deležnikov ter lokalnih skupnosti. Ena od ključnih tem v tem soočanju je bil ravno razvoj turizma (prim. Bajuk Senčar, 2014; Vranješ, 2008, str. 171-202).

Zgodovinsko gledano so se torej razlogi za ustanavljanje parkov od poudarka na turizmu in rekreaciji premaknili izrazito v področje ohranjanja narave. Razvoj turizma pa je šel obratno pot: če sta se v preteklosti rekreacija in obiskovanje parkov dogajala v zelo omeje- 
nem obsegu, se vsaj od 9o-ih let 20. stoletja dalje, s povečanjem mobilnosti, kupne moči, spreminjanjem življenjskih stilov in krepitvijo okoljske ozaveščenosti, število obiskovalcev povečuje tako hitro, da v številnih zavarovanih območjih glavna tema danes ni »diverzifikacija " turizma, ampak predvsem upravljanje, to je omejevanje in usmerjanje obiska (prim. Wearing in Neil, 1999, str. 40-41).

Po oceni Mednarodne zveze za ohranjanje narave (International Union for Conservation of Nature) zavarovana območja različnih kategorij danes obsegajo okoli $15 \%$ svetovnega kopnega, delež pa je vseskozi v porastu (The UneP World Conservation Monitoring Centre in International Union for Conservation of Nature, 2016, str. 30). Za razumevanje razvoja turizma je potrebno razlikovati med različnimi oblikami zavarovanih območij z vidika njihovih specifičnih namenov, saj so skladno s temi opredeljeni režimi in oblike varovanja okolja, s tem pa določene tudi možnosti in omejitve glede razvoja turizma. Večina ustanoviteljev zavarovanih območij, še posebej držav, se pri opredeljevanju njihovih namenov naslanja na sedem kategorij zo, kot jih na globalni ravni opredeljuje Mednarodna zveza za ohranjanje narave, ki je najpomembnejša krovna mednarodna organizacija na področju naravovarstva (International Union for Conservation of Nature, b.l.). Od teh kategorij je v veliki meri odvisno, kakšna zvrst in v kakšnem obsegu se bo turizem razvijal.

Če kljub temu posplošeno povzamemo osnovne namene večine zavarovanih območij (kot jih vidijo tako Mednarodna zveza za ohranjanje narave kot ustanovitelji in upravljavci), je poleg glavnega cilja, ki je seveda varovanje narave, večini parkov skupno to, da med njihove namene sodijo tudi varovanje kulturne dediščine, zlasti pa izobraževanje, spodbujanje trajnostnega razvoja lokalnih skupnosti ter omogočanje in usmerjanje obiska (prim. npr. Zakon o Triglavskem narodnem parku (ZTNP-1), 2010; Wearing in Neil, 1999, str. 39-56). Pomemben del poslanstva zavarovanih območij in s tem tudi nalog njihovih upravljalcev je torej neposredno ali posredno povezan s turizmom. Ker je poleg tega v zo zaradi njihovih prostorskih značilnosti (npr. težke dostopnosti) in varstvene funkcije večina oblik izkoriščanja narave zelo omejena ali prepovedana (razen trajnostnega kmetijstva, gozdarstva ipd.), je turizem pogosto edina »industrija“ oz. dejavnost, na kateri temelji razvoj lokalnih skupnosti.

Pri tem je pomembno ločiti med parkom kot zavarovanim območjem, v katerem regulatorno in razvojno vlogo igrajo različne insti- 
tucije in deležniki (vključno s turističnimi ponudniki), ter upravljalcem parka, katerega pristojnosti in naloge pa so lahko zelo različne. Upravljalci zavarovanih območij (javni ali zasebni) v razmerju do turizma lahko nastopajo v več vlogah: (a) sami organizirajo in izvajajo obiskovanje parka ter turistične programe (npr. Javni zavod Park Škocjanske jame); (b) sodelujejo z drugimi ponudniki pri spodbujanju razvoja in izvajanju turističnih programov, produktov, dogodkov; (c) so zgolj "posredniki" pri marketinških storitvah (infosredišča) ter urejajo in vzdržujejo osnovno interpretacijsko infrastrukturo (npr. Javni zavod Triglavski narodni park); (č) vsi pa sodelujejo pri sprejemanju varstvenih režimov ter nadzoru in skrbi za uveljavljanje teh režimov, kot je npr. omejevanje oz., če uporabimo mod(er)nejši izraz, usmerjanje obiskovalcev. Glavnino turističnih dejavnosti v večini parkov izvajajo različni lokalni in nelokalni ponudniki, upravljalec pa zlasti skrbi za to, da se to dogaja skladno z nameni parka, torej okolju prijazno in trajnostno. $\mathrm{V}$ tej vlogi naj bi tudi sodelovali pri sprejemanju strateških dokumentov oz. razvojnih usmeritev, ki jih pripravljajo turistične destinacijske organizacije.

\section{Trendi in zvrsti turizma v zavarovanih območjih narave}

Namenoma ali ne, zelene lise na zemljevidih sveta predstavljajo blagovno znamko, ki ne potrebuje dodatne promocije in marketinških prijemov. zo so med najpomembnejšimi destinacijami za rekreacijo in turizem nasploh, kot ugotavlja Weaver (2006, str. 199), pa se ravno v njih izvaja tudi večina svetovnega ekoturizma. Ker sta ekoturizem in obiskovanje naravnih vrednot, pa tudi rekreacija v relativno neokrnjenem (dobro ohranjenem) naravnem okolju, v izjemnem porastu, je tako tudi z obiskom zavarovanih območij (Balmford idr., 2009; Balmford idr., 2015). Mnogim parkom težavo predstavlja že dejstvo, da nimajo natančnih podatkov o številu obiskovalcev, saj gre pogosto za dnevne obiskovalce, ki v park vstopajo neorganizirano. Realna ocena obsega tovrstnega turizma je zato zelo težka. Kljub temu so Balmford in kolegi (2015) skušali izračunati obseg obiska v zo na svetovni ravni in prišli do, po njihovem mnenju dokaj realne, ocene 8 milijard obiskov letno, od tega naj bi bilo 80 \% obiska v Evropi in Severni Ameriki. Na tej podlagi so ocenili tudi ekonomski pomen obiskovanja zo: svetovno neposredno potrošnjo (brez posredne in inducirane), povezano z obiskovanjem naravnih parkov, so ocenili na 600 milijard dolarjev letno, kar bi pomenilo kar slabo tretjino (30\%) 
neposredne svetovne turistične potrošnje (Balmford idr., 2015, str. 34). Četudi te ocene vzamemo za nekoliko pretirane, se moramo strinjati, da je turizem $\mathrm{v}$ zavarovanih območjih pomemben tako po obsegu kot $\mathrm{z}$ vidika neposrednih in posrednih prihodkov. Izraz tega je navsezadnje dejstvo, da v turistično "razvitem svetu« ključno vprašanje ni, kako promovirati in nadgrajevati ponudbo v zo, ampak, kako upravljati z obiskom. Ne le Barcelona in Benetke, tudi številni naravni parki se soočajo s prekomernim turizmom in z vprašanjem omejevanja posledic tega.

Turizem v "neokrnjeni naravi« in v zavarovanih območjih je po obsegu med najpomembnejšimi zvrstmi turizma tudi v Sloveniji. $\mathrm{V}$ redkih parkih, kjer zaradi vstopnine beležijo podatke, je od konca gospodarske krize obisk v izjemnem porastu (npr. Regijski park Škocjanske jame, Krajinski park Sečoveljske soline), k čemur je gotovo pripomogla tudi sodobna infrastruktura s privlačnimi interpretativnimi sredstvi (npr. Naravni rezervat Škocjanski zatok). Glede na rezultate anket tujih turistov v Sloveniji lahko posredno sklepamo enako: med motivi obiska je najpomembnejši "produktni« motiv ohranjena narava, med geografskimi enotami pa največji delež turistov (30\%) obišče gore. Tam ležeče občine oz. destinacije v zadnjih letih beležijo najhitrejšo rast turističnih prihodov (glej https://pxweb.stat.si), in končno, poročila o prekomernem turizmu v Sloveniji ne prihajajo (le) iz Ljubljane ali z Obale, ampak tudi z območja Julijskih Alp.

Lahko se strinjamo z Weaverjem, da so razlogi, da večina ekoturizma poteka v zo, logična posledica njihovih posebnosti: običajno so zavarovane izjemne naravne atrakcije; ravno zaradi zavarovanja so te atrakcije in ekosistemi ohranjeni; zaradi režimov varovanja (omejitev) je tendenca razvoj neinvazivnih, okolju prijaznih, trajnostnih oblik turizma; razvoj turizma je v teh območjih pomemben vir dohodka; v zo je pogosto poudarek na "okoljskem « izobraževanju in ozaveščanju; na turističnem trgu so zo prepoznavna blagovna znamka. Med »zunanjimi« dejavniki pa na splošno lahko izpostavimo, da je koncentracija ekoturizma v zo preprosto posledica tega, da je izven teh območij narava izpostavljena degradaciji in je zato pritisk ekoturističnega povpraševanja iz urbaniziranega sveta na ta območja toliko večji. V nekaterih državah z manj diverzificirano turistično ponudbo se turizem celo izrazito koncentrira ravno v zo in njihovi neposredni okolici (Weaver, 2006, str. 198-201). 
Če se lahko strinjamo, da večina ekoturizma poteka v zo, pa ne moremo trditi tudi obratno. Še zlasti v gospodarsko »razvitih državah« je s porastom zanimanja za rekreacijo v naravi značilen trend nenehna diverzifikacija turistične ponudbe in motivov obiskovanja zo. Lahko rečemo, da se v zadnjih dveh, treh desetletjih porast obiskovanja v manjši meri dogaja na račun »trdega« ekoturizma, dogaja se zlasti na račun "množičnega« obiskovanja atrakcij ter različnih oblik rekreacije in sprostitve v naravi. Po drugi strani je delitev na ekoturista in rekreativca, užitkarja, počitnikarja lahko preveč enostavna. "Sveti« kriteriji opredelitve ekoturizma so namreč trije: (1) obisk relativno ohranjenih naravnih atrakcij (2) z namenom izobraževanja, spoznavanja in občudovanja naravnih in kulturnih značilnosti okolja, in sicer (3) z izvajanjem na trajnosten način, tj. na način, ki ne ogroža, ampak obratno, pripomore (tudi finančno) k ohranjanju narave in k razvoju lokalnih skupnosti (Weaver, 2006, str. 192-194; Wearing in Neil, 1999, str. 7-9). Ali nekega rekreativca lahko uvrstimo v segment ekoturizma je bolj vprašanje naše opredelitve kot njegove motivacije: je občudovanje, spoznavanje narave skozi aktivnosti, ki le-te ne ogrožajo, ekoturizem ali (širše) »outdoor« turizem? Tukaj si lahko pomagamo z Weaverjevim razlikovanjem na »trše« in "mehkejše« idealnotipske značilnosti ekoturizma, kot je prikazano na sliki 10.1. Če privzamemo takšno diferenciacijo, potem je trdi ekoturizem v svetu po obsegu v manjšini, dogaja se v majhnih skupinah in razpršeno izven vročih turističnih točk, prevladuje pa mehkejši ekoturizem, ki je večinoma prostorsko skoncentriran na popularna naravna območja in znamenitosti, kot sta v Sloveniji na primer obisk TNP ali Škocjanskih jam (slika 10.2). Pri tem je potrebno upoštevati tudi časovno komponento, torej trajanje in letni čas obiska.

Če izvzamemo najstrožja zavarovana območja narave, kjer je obiskovanje zelo omejeno ali celo prepovedano, bi lahko poenostavljeno rekli, da imamo danes $v$ naravnih parkih paleto sledečih motivov obiskovanja in z njimi povezanih segmentov turizma:

- "klasični« in trdi ekoturizem: spoznavanje, opazovanje in izobraževanje o naravi je v ospredju (npr. obisk amazonskega pragozda, fotosafari);

- izobraževalni turizem za specifične populacije (npr. programi za skupine šolske populacije);

- množični mehki ekoturizem: obiskovanje naravnih znamenito- 


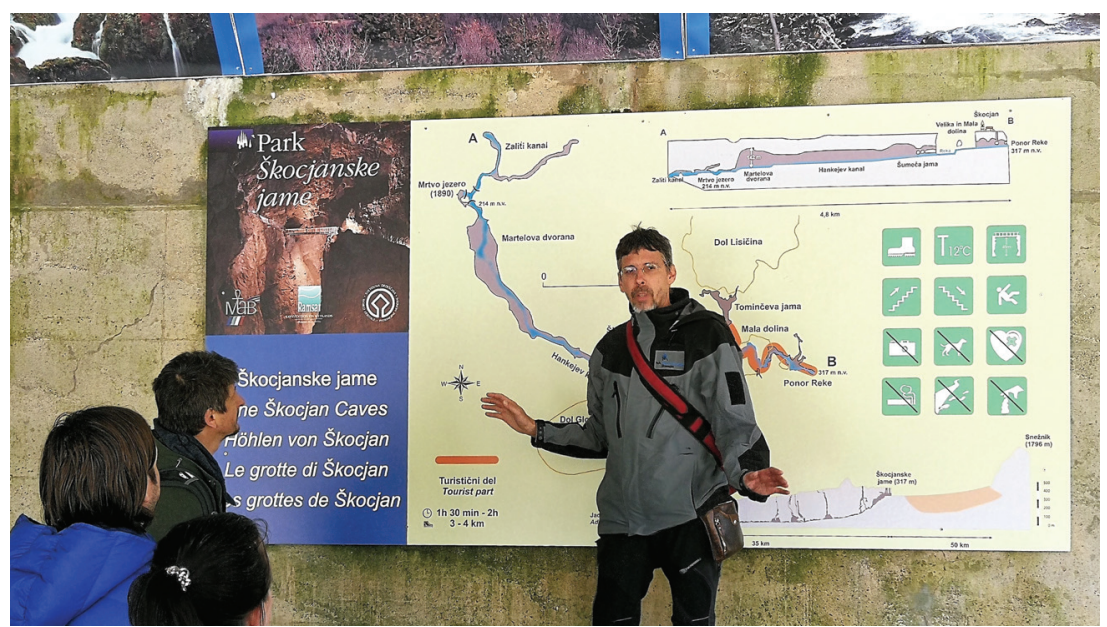

Slika 10.2 Obisk Škocjanskih jam v manjši skupini izven glavne turistične sezone se z daljšim vodenjem in s poglobljeno interpretacijo približa trši obliki ekoturistične izkušnje (foto Simon Kerma)

sti, kjer je spoznavanje manj poglobljeno, a prisotno (npr. obisk Galapagosa, Blejskega Vintgarja);

- obiskovanje in spoznavanje kulturne dediščine, kulturnih atrakcij in posebnosti (npr. ekoloških kmetij, muzejev, solin);

- počitnikovanje in sprostitev v nedotaknjenem naravnem okolju, pogosto $\mathrm{z}$ »zdravstveno« noto (bivanje v počitniških domovih, sprehodi, vikendaštvo);

- rekreacija v naravnem okolju oz. aktivni/»outdoor« turizem v ožjem pomenu (kolesarstvo, pohodništvo, alpinizem, padalstvo, turno smučanje itd.).

V gospodarsko "razvitejših državah" (Evropa, Severna Amerika, Avstralija) so med turističnimi segmenti nedvomno v ospredju obiskovanje in občudovanje naravnih znamenitosti (in kulturne dediščine) ter rekreacija v naravnem okolju, skratka dejavnosti, ki bi jih po Godfrey-Smithu (1980, v Wearing in Neil, 1999, str. 12) lahko združili pod pojmovanje narave kot bodisi »katedrale« bodisi »telovadnice«. Na drugi strani je segment »narave kot učilnice«, poglobljeni izobraževalni programi, po obsegu manjši - običajno gre za izraziti nišni turizem, namenjen manjšim skupinam in šolskim populacijam. To potrjujejo npr. tudi rezultati ankete, ki so jo nedavno opravili med obiskovalci Triglavskega narodnega parka (slika 10.3). 
Vzpon na katerikoli vrh v TNP Obisk naravnih in kulturnih znam.

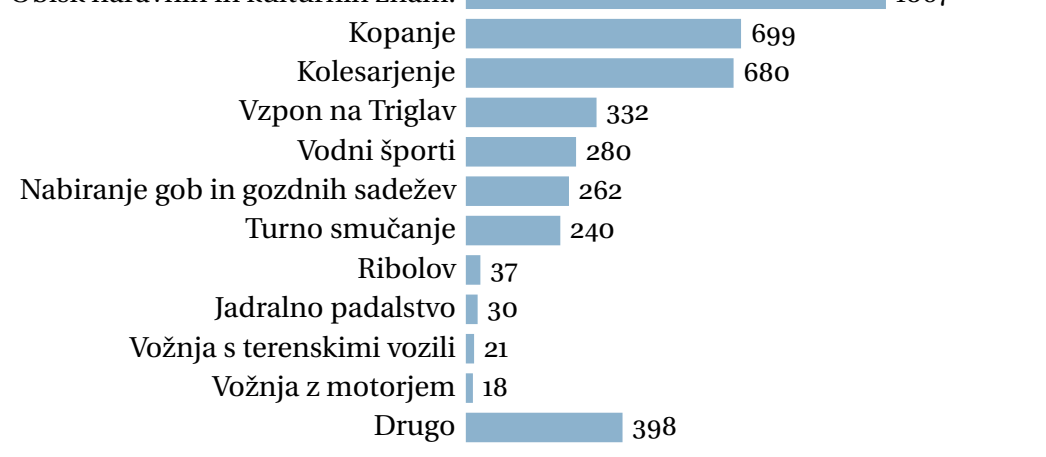

Slika 10.3 Aktivnosti anketiranih obiskovalcev na območju TNP

(prirejeno po Javni zavod Triglavski narodni park, 2017, str. 50)

Ne glede na obliko in "trdoto « ekoturizma v splošnem velja, da turizem v zo večinoma izvajajo zasebni ponudniki, zaradi česar sta delež prihodkov, namenjen ohranjanju narave, ter odtekanje dobička izven lokalnih okolij lahko zelo različna - tudi s tem v zvezi bi lahko govorili o trših in mehkejših oblikah ekoturizma. Po drugi strani o pravem ekoturizmu praviloma lahko govorimo v primerih, ko obisk organizirajo upravljavci zo sami. Prvič zato, ker je ena od njihovih standardnih nalog ravno izvajanje izobraževanja in skrb za interpretacijo narave, ter drugič zato, ker se prihodki nedvomno vračajo za namene ohranjanja narave. Upravljalci parkov praviloma skrbijo za razvoj izobraževanih oz. interpretacijskih vsebin in programov ter $\mathrm{v}$ ta namen urejajo in vzdržujejo infrastrukturo, ki je na voljo obiskovalcem, s tem pa posredno ali neposredno drugim ponudnikom. Pri tem se poslužujejo različnih prijemov in oblik interpretacije: informacijskih središč in razstav; izobraževalnih središč za izvajanje delavnic oz. programov; publikacij in medijskih objav; urejanja učnih poti $\mathrm{z}$ interpretacijo in-situ in on-line; vodenih izletov $\mathrm{z}$ razlago. $\mathrm{V}$ ekoturizmu in zo je kakovostna interpretacija zelo pomembna, saj ima večplasten pomen in učinek na več ravneh: po eni strani krepi okoljsko ozaveščenost ter spodbuja spremembe v odnosu družbe do narave nasploh; privablja obiskovalce in s tem pozitivno vpliva na razvoj turizma, dosega odpiranje delovnih mest oz. trajnostni razvoj lokalnih skupnosti; izboljšuje kakovost doživetja skupin, katerih primarna motivacija ni nujno izobraževanje (ampak, denimo, rekreacija); z ustreznimi sporočili je lahko prijazna tehnika upravlja- 
nja in usmerjanja obiskovalcev - preko ozaveščanja o pravilih vedenja in gibanja v občutljivem naravnem okolju prispeva k omejevanju (potencialno) negativnih učinkov obiska na ranljivo naravno okolje (prim. Wearing in Neil, 1999, str. 57-70).

Porast ekoturizma in še posebej obiskovanja parkov je v veliki meri povezan s spremembami v življenjskih stilih ter odnosom (post)industrijske družbe do narave. To se izraža tudi v poskusih orisa tipičnega profila obiskovalca zo. Če izvzamemo turiste, ki naravne atrakcije obiskujejo kot pač še eno postajo v svojem osebnem ali agencijskem počitniškem itinerarju, obiskovalce zo lahko poenostavljeno opredelimo kot ljubitelje narave in/ali ljubitelje »outdoor" aktivnosti. Thomas Feil je v svoji prestavitvi na Parks \& Benefits Marketing Workshop leta 2009 npr. "povprečnim« obiskovalcem zo pripisal sledeče demografske značilnosti: predstavniki mlajše ali srednje generacije, s povprečnimi ali nadpovprečnimi prihodki, najmanj srednješolska izobrazba, živeči v veččlanskem gospodinjstvu (Fieber 2012, str. 129). "Skupne« naj bi jim bile zlasti sledeče značajske in kulturne lastnosti: močan občutek odgovornosti do sebe in družine; zanimanje za družbeno pomembne teme; veliko zanimanje za naravo, trajnostni razvoj in visoka okoljska ozaveščenost; ljubitelji "outdoor« aktivnosti; cenijo čisto, nedotaknjeno naravo. Povprečni obiskovalci zo potujejo v majhnih skupinah, želijo si neposrednega doživljanja narave, kakovost v smislu "razkošja» se jim ne zdi pomembna, v glavnem so izkušeni turisti oz. popotniki (prim. Wearing in Neil, 1999, str. 119-129). Seveda bi tudi lastnosti povprečnega obiskovalca zo lahko raztegnili na os med mehkimi in trdimi ekoturisti: za razliko od mehkih, denimo, pravi, trdi ekoturist pričakuje poglobljene informacije in izobraževanje o ciljni destinaciji. Lahko tudi rečemo, da so interesi trdega ekoturista povsem kompatibilni z nameni in s cilji zavarovanih območij, kar pa za mehkega ekoturista in ljubitelja rekreacije ne moremo trditi.

\section{Izzivi upravljanja z obiskom in razvoja (eko)turizma v zavarovanih območjih}

Za razliko od ostalih ekoturističnih destinacij in zvrsti je v zo upravljanje $\mathrm{z}$ obiskom, tj. sprejemanje in izvajanje ukrepov za preprečevanje negativnih učinkov na okolje, ključen vidik razvoja turizma. Zaradi hitre rasti števila obiskovalcev ter povečevanja interesa za razvoj in diverzifikacijo produktov v zo je danes upravljanje z obi- 
skom oz. razvoj trajnostnega turizma ena od najaktualnejših tem, tudi na mednarodni ravni (gl. npr. Leung idr., 2018). Za začetek sta pred mnogimi upravljavci zo dva izziva: ugotavljanje števila in smeri gibanja obiskovalcev ter določanje dopustnih meja obsega obiskovanja. Če se z razvojem tehnologije ocene o številu in gibanju obiskovalcev izboljšujejo, pa je ugotavljanje učinkov povečanega ter zlasti novih oblik obiskovanja precej težja naloga. Povsem zmotno je »laično" pričakovanje, da je z obstoječimi metodami mogoče določiti zgornjo meja obiska, kot to npr. sugerira izraz »nosilna zmogljivost«. V veliki večini primerov ni tako, saj učinki obiskovanja niso enostavno merljivi oz. določljivi in je posledično napovedovanje možnih posledic povečanega obiska nehvaležna naloga. Posledice so slejkoprej zaznane empirično, ko se že zgodijo. Toliko težje je napovedovati vpliv rekreacijskih dejavnosti, ki se pojavljajo šele v zadnjem času. Določanje »nosilne zmogljivosti« v tem kontekstu je, skratka, precej subjektivne narave (Wearing in Neil, 1999, str. 53). Ravno zato upravljalci vzpostavljajo sistem rednega in hkratnega spremljanja števila obiskovalcev in stanja okolja, ki jim omogoča, da na podlagi zaznanih sprememb pravočasno ukrepajo. Druga možnost določanja "meja« je nekoliko radikalnejša. Še zlasti v primeru novih oblik rabe prostora se upravljalci lahko zatečejo k t.i. načelu previdnosti. Njegovo bistvo je v tem, da je v primeru dvoma o neobstoju škodljivih vplivov neke dejavnosti treba predpostaviti, da ti obstajajo (Klemenčič, 2010). V praksi to pomeni, da takrat, ko posledic neke dejavnosti ne znamo predvideti, dejavnost »iz previdnosti« omejimo.

Pri izvajanju usmerjanja in omejevanja obiskovanja se v zo uporablja različne metode oz. kombinacijo metod. Neposredna omejitev števila obiskovalcev je mogoča tam, kjer obstaja sistem vstopnin ali vsaj omejeno število vstopnih točk. Najpogosteje je v uporabi coniranje, tj. opredeljevanje območij (con), v katerih so določene zvrsti, načini in obdobja dovoljene rabe, uveljavlja pa se z nadzorovanjem in s sankcioniranjem. Načrtovanje in vzdrževanje urejenih poti je do obiskovalcev prijazna posredna tehnika, s katero se spodbuja obiskovanje določenih predelov, medtem ko se ranljiva območja zaobide.

Ključnega pomena sta tudi izobraževanje in ozaveščanje, saj je zaradi velikosti zo smiselno računati na sodelovanje in "samonadzor « obiskovalcev (Wearing in Neil, 1999, str. 52-56). Ne glede na uporabljene metode se poleg tega usmerjanje obiskovalcev lahko ravna po 
dveh načelih: načelo redistribucije zaradi zmanjševanja pritiska teži k razpršitvi obiska na večje območje, načelo koncentracije pa, obratno, teži h koncentraciji obiska na izbranih točkah z namenom, da se ostala območja ohranja »neokrnjena«.

Zaključimo lahko, da so izzivi ekoturizma $\mathrm{v}$ zo in nasploh vezani zlasti na razpetost med ohranjanjem narave in podpiranjem trajnostnega razvoja lokalnih skupnosti v času, ko izjemno zanimanje za turizem v naravi prinaša tako priložnosti kot grožnje. Ključno vprašanje seveda je, kako razvijati turizem, ki bo prispeval k ohranjanju naravnega okolja in kulturne dediščine, hkrati pa omogočal ohranjanje poselitve, pogoje za življenje in razvoj lokalnih skupnosti. Glede na temeljne cilje in namene zo je turizem še najsprejemljivejša, okolju prijazna gospodarska dejavnost, od katere so lokalne skupnosti vedno odvisnejše. Lokalne skupnosti so namreč deležne precejšnjih omejitev glede ostalih oblik rabe prostora, naravnih virov ter možnosti gospodarskega razvoja. S tem povezano je končno tudi vprašanje porazdelitve stroškov in koristi: ko namreč turizem v zo izvajajo pretežno zunanji (nelokalni) ponudniki, lokalno prebivalstvo nosi stroške (omejitve), ne pa tudi koristi.

Na drugi strani je pritisk turistične industrije, lokalne in nelokalne, po rahljanju omejitev precejšen. Pri »usmerjanju« razvoja turizma v zo se upravljalci soočajo z interesi različnih deležnikov: naravovarstvenih organizacij, okoljske politike, turističnih ponudnikov, lokalnih skupnosti ter posebnih skupin uporabnikov, kot so npr. rekreativci, ribiči, kmeti, gozdarji, solinarji ipd. Ne glede na nehvaležno nalogo bi moral biti razvoj (eko)turizma v interesu upravljavcev zo tudi s finančnega vidika. Čeprav je pri zo potrebno imeti pred očmi tudi njihove "neekonomske« koristi (Wearing in Neil, 1999, str. 4345), je zanimiva realnost ta, da so sredstva, ki se vlagajo v zo, neprimerno nižja, kot so prihodki z naslova njihovega turističnega trženja (Balmford idr., 2015). Številna zo, tudi v »razvitem svetu«, pa iz javnih blagajn ne prejemajo ustreznih sredstev za opravljanje osnovnega poslanstva. Tako za naravovarstvenike kot lokalne skupnosti, turistične ponudnike in obiskovalce bi moral biti ekoturizem ena od boljših »rešitev«. Ni pa edina.

\section{Literatura}

Bajuk Senčar, T. (2014). Načrt upravljanja Triglavskega narodnega parka in kultura dediščinskih praks. V J. Fikfak, T. Bajuk Senčar in D. Podjed 
(ur.), Triglauski narodni park: akterji, dediščine (str. 9-26). Založba ZRC.

Balmford A., Beresford J., Green J., Naidoo, R., Walpole, M., in Manica, A. (2009). A global perspective on trends in nature-based tourism. PLoS Biol, 7(6), članek e1000144. https://doi:10.1371/journal.pbio.10o

Balmford, A., Green J. M. H., Anderson M., Beresford, J., Huang, C., Naidoo, R., Walpole, M., in Manica, A. (2015). Walk on the wild side: Estimating the global magnitude of visits to protected areas. PLoS Biol, 13(2), članek e1002074. https://doi:10.1371/journal.pbio.1002074

Bodi eko. (B. 1.). Kaj je ekoturizem. https://www.bodieko.si/kaj-je .ekoturizem

Budowski, G. (1976). Tourism and environmental conservation: Conflict, coexistence, or symbiosis? Environmental Conservation, 3(1), 27-31.

Ceballos-Lascuráin, H. (1988, 27. januar). The future of 'ecotourism.' Mexico Journal, 13-14.

Choo, H., in Jamal, T. (2009). Tourism on organic farms in South Korea: A new form of ecotourism? Journal of Sustainable Tourism, 17(4), 431454.

Fennell, D. (1999). Ecotourism: An introduction. Routledge.

Fennell, D. A. (2008). Ecotourism (3. izd.). Routledge.

Fieber, S. (2012). Developing and marketing ecotourism products. V Guide to sustainable tourism in protected areas (str. 127-133). Parks \& Benefits. https://www.europarc.org/wp-content/uploads/2015/05/ 2012_Parks_and_Benefits_Guide_to_sustainable_tourism_in _Protected_Areas.pdf

Godfrey-Smith, W. (1980). The value of wilderness: A philosophical approach. V R. W. Robertson, P. Helman in A. Davey (ur.), Wilderness management in Australia: Proceedings of a symposium held at the Canberra College of Advanced Education 19th-23rd July 1978 (str. 5671). College of Advanced Education.

Hunt, C. A., in Stronza, A. (2009). Bringing ecotourism into focus: Applying a hierarchical perspective to ecotourism research. Journal of Ecotourism, 8(1), 1-17.

International Union for Conservation of Nature. (B. 1.). Protected area categories. https://www.iucn.org/theme/protected-areas/about/ protected-area-categories

Javni zavod Triglavski narodni park. (2017). Turistični obisk biosfernega območja Julijske Alpe [interno gradivo].

Jurinčič, I. (2009). Nosilna zmogljivosti Slovenske Istre za turizem. Fakulteta za turistične študije - Turistica.

Kerma, S., Lampič, B., in Podmenik, D. (2014). Tourism as a supplementary activity on organic farms in the Primorska region, Slovenia. Academica Turistica, 7(2), 101-112. 
Klemenčič, T. (2010). Načelo previdnosti in primeri njegove uporabe $\mathrm{v}$ praksi. Varstvo narave, 23(23), 67-75.

Leung, Y., Spenceley, A., Hvenegaard, G., in Buckley, R. (ur.). (2018). Tourism and visitor management in protected areas: Guidelines for sustainability (Best Practice Protected Area Guidelines Series No. 27). International Union for Conservation of Nature.

McCormick, J. (1995). The global environmental movement. Wiley.

McManus, P. (2000). National parks. V R. J. Johnston, D. Gregory, G. Pratt in M. Watts (ur.), The dictionary of human geography (str. 532-533). Blackwell.

Mihalič, T. (2006). Trajnostni turizem. Ekonomska fakulteta.

Nowaczek, A., in Smale, B. (2010). Exploring the predisposition of travellers to qualify as ecotourists: The ecotourist predisposition scale. Journal of Ecotourism, 9(1), 45-61.

Naravni rezervat Škocjanski zatok. (2020). Ponudba. https://www .skocjanski-zatok.org/ponudba/

Perkins, H., in Grace, D. A. (2009). Ecotourism: Supply of nature or tourist demand? Journal of Ecotourism, 8(3), 223-236.

Podmenik, D., Jurinčič, I., Balažič, G., Horvat, A., in Kerma, S. (2012). Turizem na ekoloških kmetijah v Sloveniji. V D. Podmenik (ur.), Trendi in perspektive ekološkega kmetijstva s poudarkom na Sloveniji in Slovenski Istri (str. 129-142). Vega.

Primožič, T. (2014). Ekoturizem in možnosti njegovega udejanjanja $v$ Slovenski Istri [neobjavljeno diplomsko delo]. Univerza na Primorskem.

Québec declaration on ecotourism. (2002). https://www.gdrc.org/uem/ eco-tour/quebec-declaration.pdf

Rotich, D. (2012). Concept of zoning management in protected areas. Journal of Environment and Earth Science, 10(2), 173-183.

Slovenska turistična organizacija. (2019). Turizem v številkah 2018 [brošura]. https://www.slovenia.info/uploads/dokumenti/raziskave/tvs _2018/tvs_2018-web.pdf

The International Ecotourism Society. (2015). What is ecotourism? https: //ecotourism.org/what-is-ecotourism/

The UnEP World Conservation Monitoring Centre in International Union for Conservation of Nature. (2016). Protected planet report 2016.

Turistična zveza Slovenije. (2003). Razvoj ekoturizma v Sloveniji: prispevki posvetovanja (Zbirka Turistična misel 13).

World Tourism Organization. (2020). Ecotourism and protected areas. https://www.unwto.org/sustainable-development/ecotourismand-protected-areas

Vranješ, M. (2008). Prostor, teritorij, kraj: produkcije lokalnosti v Trenti in na Soči. Annales. 
Wearing, S., in Neil, J. (1999). Ecotourism: Impacts, potentials and possibilities. Butterworth-Heinemann.

Weaver, B. D. (2001). The Encyclopedia of Ecotourism. САвI.

Weaver, B. D. (2006). Sustainable tourism: Theory and practice. Elsevier Butterworth-Heinemann.

Wight, P. (2001). Ecotourists: Not a homogeneous market segment. V B. D. Weaver, The encyclopedia of ecotourism (str. 37-62). САВ I.

Zakon o Triglavskem narodnem parku (ZTNP-1). (2010). Uradni list Republike Slovenije, (52). https://www.uradni-list.si/1/objava.jsp?sop =2010-01-2821 